\title{
THE IMPORTANCE OF TANGIBLE FIXED-ASSETS REVALUATION: A COMPARISON BETWEEN ROMANIAN ACCOUNTING REGULATIONS AND THE IPSAS 17 'PROPERTY, PLANT AND EQUIPMENT'
}

\author{
Nicoleta Cristina Matei, ${ }^{1}$ Marin Ţole, ${ }^{2}$ Mihaela Andreea Stroe ${ }^{3}$
}

\begin{abstract}
The purpose of a tangible fixed-assets revaluation is to establish true values for assets and a genuine picture of the financial position and the result of public institutions. This article presents the legislation needed to implement international provisions regarding the accounting system of public institutions, especially those concerning the revaluation of tangible fixed assets. It contains a comparison between the national regulations and guidelines of the International Public Sector Accounting Standard for tangible fixed assets. It highlights the convergences and divergences regarding the accounting treatment for determining the initial value of tangible fixed assets, the setting out of the reassessed value, the accounting treatment applied to the revaluation results, and the achievement of a revaluation surplus. It also describes the manner in which the revaluation of tangible fixed assets can influence the financial and patrimonial position of a public institution.
\end{abstract}

JEL Classification Numbers: M41; DOI: http://dx.doi.org/10.12955/cbup.v5.944

UDC Classification: 657

Keywords: tangible fixed-assets revaluation, initial value, fair value, financial position, result of public institutions

\section{Introduction}

Since 2005, coinciding with the adoption of the methodological norms, the accounting system of public institutions underwent a comprehensive reform to adapt to the new economic, political, legal, and social context. An objective of the reform is to implement international accounting standards in the public sector. However, the current national accounting regulations have inconsistencies with the provisions of international standards.

This study investigates statements relating to the converging and diverging aspects of adapting the national accounting regulations to the international standards of public sector accounting regarding the revaluation of tangible fixed-assets. These include the accounting treatments applied to determine the value of tangible fixed-assets at the balance sheet date; the new provisions concerning the revaluation of fully depreciated tangible fixed-assets; and how the revaluation of tangible fixed-assets influence the financial position and the patrimony of a public institution.

\section{Literature review}

As Ristea and Jianu (2010) wrote, the ever-increasing need for information in the public system as well as the need to provide comparable and transparent information have led to the development and popularization of the International Public Sector Accounting Standards (IPSAS).

Luca (2010) identifies how the accrual accounting principles, as well as the international regulatory framework for public accounting, were considered in developing the methodological norms for organizing and operating the accounting departments of public institutions adopted by the Minister of Public Finance Order No. 1917/2005.

According to Luca (2010) the transition to accrual accounting was manifested amid extensive financial and accounting changes, which include the adoption of the following: Law No. 500/2002 on public finance; new budget classification in compliance with the European System of Accounts (ESA) 1995; Government Ordinance No. 81/2003 on revaluation and depreciation of fixed-assets owned by public institutions; and modification, addition, and republishing of the Accounting Law No. 82/1991.

\section{Data and Methodology}

The study involved normative research in analyzing the manner in which the IPSAS 17 'Property, Plant and Equipment' provisions are implemented under the national accounting regulations for revaluating

\footnotetext{
${ }^{1}$ PhD Lecturer, Faculty of Economics and Business Administration, Nicolae Titulescu University, Bucharest, Romania, cmatei@univnt.ro

${ }^{2}$ Professor, Faculty of Domestic and International Commercial and Financial Banking Relations, Romanian-American University, Bucharest, Romania, tole.marin@yahoo.com

${ }^{3}$ PhD Lecturer, Faculty of Economics and Business Administration, Nicolae Titulescu University, Bucharest, Romania, stroeandreea@univnt.ro
} 
tangible fixed assets. It was considered that because the tangible fixed-assets are elements that hold a significant share in the patrimony of public institutions in Romania, their 'balance-sheet' value had special importance in decision-making.

\section{Results and Discussion}

Accounting Treatments on Establishing Tangible Fixed-assets Initial Value

Fixed assets represent resources controlled by a public institution as a result of past events that are expected to generate future economic benefits for the institution, having a realistically measured cost and which are held with a view for long-term use.

As shown in the Minister of Public Finance Order No. 1917 of 2005, tangible fixed-assets are regarded as an item or, cumulatively, a set of items that meet certain criteria. These criteria include 1) their input value is higher than the limit established by government order and 2) the period of their normal use is greater than one year.

The IPSAS 17 'Property, Plant and Equipment' has no minimum value for recognizing assets as tangible fixed assets, but rather refers to the purpose of acquiring the goods, the employment period, and the cost, which must be realistically measured. The entity retains any future economic benefits associated with the asset.

The tangible fixed assets, both according to the national accounting regulations and the IPSAS 17 'Property, Plant and Equipment', are initially to be evaluated by cost when acquired for consideration or produced by the institution, or by a fair value when obtained free of charge. In this latter case, fair value is not an object for revaluation but represents an amount for which the asset could be willingly exchanged between two knowledgeable parties, in the context of a transaction with an objective set price (Luca, 2010).

The initial cost of a tangible fixed asset can either equal the acquisition cost, in the case of acquiring goods for consideration, or the production cost of goods manufactured by direct labor.

The initial cost of any tangible fixed asset obtained for consideration includes the purchase price, nonrecoverable expenses related to the purchase, and any other expenses directly attributable to acquiring the asset, apart from the trading discounts under national regulations. The international accounting standards for the public sector mention that, upon the initial recognition of a tangible fixed asset, one must include in its cost of acquisition the nonrecoverable expenses. Any costs are directly attributable to conveying the asset to the location and provided the conditions necessary for it to function in the manner intended by management.

According to the Minister of Public Finance Order No. 1917 of 2005, the acquisition cost of raw materials, consumables, and production expenses that are directly attributable to the asset are part of the production costs.

The initial cost of an asset plays a critical role in establishing its accounting value, a value against which one compares a fair value, obtained as a result of revaluation, to determine a difference.

\section{Revaluation as a Procedure to Establish Fixed Tangible Assets Current Value}

The annual financial statements of a public institution, according to the national accounting regulations, must provide a true picture of the total assets, liabilities, financial position, and performance as well as any patrimony. This requires public institutions to present their tangible fixed assets at the end of the financial exercise as well as the balance sheets showing the assets at their 'real' value, a value that can be determined by a basic accounting treatment, an allowed alternative, or by revaluation, respectively.

Both the national accounting regulations and the IPSAS 17 'Property, Plant and Equipment" stipulate provisions that allow public institutions to opt for one of two treatments for setting the value of the tangible fixed assets, as at the balance sheet date.

According to the basic accounting treatment, tangible fixed assets can be presented as at the balance sheet date, as a cost under accumulated depreciation or accumulated depreciation loss, whereas according to the allowed alternative treatment, they can be presented as their revaluated value.

The revaluation of tangible fixed assets updates their value to one considered a fair value.

The fair value is usually determined by a member of the evaluation profession and, generally speaking, it amounts to the market value of goods under the IPSAS 17 'Property, Plant and Equipment'. At the 
same time, the national accounting regulations state that the fair value is determined by a commission appointed by the Head of the public institution, where where it is not established by authorized evaluators.

The commission appointed by the Head of the public institution must comprise members with the appropriate economic and technical background, and who can assess the condition, depreciation, use, and market value of tangible fixed assets subject to revaluation. The revaluation commission members establish the updated value of these assets by multiplying the accounting entry by the consumer price index, which is released on the website of the National Statistics Institute.

The national accounting regulations and the international standards provide for a reassessment with sufficient regularity so that the accounting value does not differ substantially from that which would be determined by using the fair value as at the balance sheet date. However, there are certain divergences, such as the revaluation of land and buildings, which, according to national rules on a revaluation of tangible fixed assets, must be performed at least once every three years, starting with the year 2008.

For tangible fixed assets with a market value, the fair value is the same as the market value, but there may be cases of assets that are not traded on the market. In these circumstances, the value of the assets is established according to the IPSAS 17 'Property, Plant and Equipment' based on other elements with similar characteristics, in similar circumstances and locations.

The national rules on the revaluation of tangible fixed assets owned by public institutions, provided by the Minister of Economy and Finance Order No. 3471 (2008), categorize the revaluated tangible fixed assets as follows:

- Land and land development, buildings, technical installations, means of transportation, animals, and plantations, furniture, office equipment, equipment for the protection of human and material values and other tangible fixed assets;

- Tangible fixed assets in concession, rented, or in free use for persons;

- Legal assets, without any patrimonial purpose, as well as the assets found in the administration of autonomous administrative overheads;

- Capacities commissioned in part, of the kind of tangible fixed assets that have not yet been registered as such;

- Tangible fixed assets that have undergone investment changes (modernization, repairs, rehabilitation and consolidation) that have increased their 'accounting book' value, regardless of the source of investment funding;

- Tangible fixed assets acquired by public institutions under finance leasing contracts;

- Tangible fixed assets at the diplomatic, commercial, military representations abroad, in conflict zones.

According to the Minister of Economy and Finance Order No. 3471 (2008), the fixed assets that are not subject to revaluation have the following categories:

- Tangible fixed assets that enter the patrimony of public institutions during the year when the reassessment is carried out and are recorded in books as their cost of acquisition, production, or fair value, as appropriate;

- Tangible fixed assets with a normal service life expiring at the revaluation date;

- Tangible fixed assets on conservation, as well as the mobilization reserves that are highlighted in accounting books as tangible fixed assets;

- Tangible fixed assets that have documents drawn, but the approvals for legal closure are unsettled, and the assets have not been dismantled, demolished or converted into parts; and

- Tangible fixed assets in progress.

Also, the national rules on a revaluation of tangible fixed assets contain some clarifications related to depreciable assets, namely those in the private domain of the state, the administrative-territorial units, and the private property of public institutions. Where these tangible fixed assets have common characteristics shared with the inventory objects, they are fully depreciated, and their value is less than the limit established by the government decision. They are classified in the category of 'inventory object materials in use'. Inventory object materials derived from the tangible fixed assets that are recorded in 
this category will be highlighted in the accounting books as their fair value, established by a committee of institution experts, appointed by the authorizing officer.

As previously mentioned, revaluation represents a procedure of establishing a fair value, which is the current value of the tangible fixed assets. The fair value is set up as a result of applying the alternative accounting method for determining the value of the tangible fixed assets as at the balance sheet date. As an alternative approach, public institutions can opt out of its application for the tangible fixed assets that can be revaluated. However, for land and buildings, there is a compulsory treatment established using national rules.

Accounting Treatment of Tangible Fixed-assets Revaluation Results and Influence on Financial Position and the Result of Public Institutions

According to the national rules on revaluation of tangible fixed assets, the value resulting from the revaluation will be attributed to the asset in place of the acquisition cost or the production cost, as the case may be. Therefore, in the balance sheet, the tangible fixed assets that have been revaluated will feature their revaluated worth.

The accounting books of public institutions in Romania show both depreciable and non-depreciable tangible fixed assets. In principle, the tangible fixed assets from the private domain of the state, the administrative-territorial units, the private property of public institutions and which are not represented by land, are depreciable. Their depreciation means the inclusion of a part of their initial value as an expense for the public institution until the full amount of the investment is recovered.

The following are tangible fixed assets (Government Ordinance no. 81, 2003) that are not depreciable: the property belonging to the public domain of the state and the territorial administrative units in compliance with the law, including the investments made in this property; tangible fixed assets from the patrimony of local public services performing economic activities, in which wear and tear is recovered using rate or price, in compliance with the law; tangible fixed assets on conservation, as well as the mobilization reserves that are highlighted in accounting books as tangible fixed assets; lakes and ponds that are not the result of an investment; land; property of the national cultural heritage; assets used under a lease; and goods, such as weapons and combat techniques.

According to the IPSAS 17, 'Property, Plant and Equipment', land is not depreciable as it does not have a limited service life, but all other tangible fixed assets can be depreciated.

The results of the revaluation are treated in the accounts of public institutions in Romania depending on the depreciable nature of tangible fixed assets.

The increase or decrease in value of the depreciable tangible fixed assets is calculated based on the difference between the value obtained from the revaluation and that recorded in the accounting.

The national accounting regulations and the IPSAS 17 'Property, Plant and Equipment' stipulate different methods for treating results of the tangible fixed-assets revaluation (Table 1).

\begin{tabular}{|l|l|l|}
\hline \multicolumn{3}{|l|}{ Table 1: Comparison of treatments for the results of tangible fixed-assets revaluation } \\
\hline $\begin{array}{l}\text { The Accounting } \\
\text { Tangible Fixed } \\
\text { Assets }\end{array}$ & \multicolumn{1}{|c|}{ National Accounting Regulations } & \multicolumn{1}{c|}{$\begin{array}{c}\text { IPSAS 17 'Property, Plant and } \\
\text { Equipment' }\end{array}$} \\
\hline Increases & $\begin{array}{l}\text { The increase credits the account of } \\
\text { 'revaluation reserves' and an income } \\
\text { account to the extent to which it } \\
\text { compensates a revaluation decrease of the } \\
\text { same assets, previously acknowledged as } \\
\text { expenditure }\end{array}$ & $\begin{array}{l}\text { The increase credits the account of } \\
\text { 'revaluation surplus' to the extent to } \\
\text { which it compensates a revaluation } \\
\text { decrease of the same assets, previously } \\
\text { acknowledged as expenditure }\end{array}$ \\
\hline Decreases & $\begin{array}{l}\text { The decrease debits the account of } \\
\text { 'revaluation reserves' and an expense } \\
\text { account to the extent in which it exceeds the } \\
\text { revaluation reserve detained following a } \\
\text { previous revaluation of the same assets }\end{array}$ & $\begin{array}{l}\text { The decrease will be subtracted from any } \\
\text { revaluation surplus to the extent of which } \\
\text { it does not exceed that surplus even as } \\
\text { expenditure, but only for the difference } \\
\text { that exceeds the revaluation surplus }\end{array}$ \\
\hline Source: Authors & \multicolumn{2}{|l}{} \\
\hline
\end{tabular}

The accounting treatment of results from the tangible fixed-assets revaluation, for international regulations and standards, is similar to the treatment of the national regulations, except that the national 
accounting regulations apply this treatment to the results of the revaluation of depreciable tangible fixed assets.

The results of the revaluation of non-depreciable tangible fixed assets are treated, in compliance with national rules, as follows:

- as an increase in the revaluation reserve which is simultaneously transferred into the credit of the funds' account where the revaluation result is an increase in the accounting value; and

- as a decrease in the revaluation reserve which is simultaneously transferred to the debit side of the funds' account where the revaluation result is a decrease in the accounting value.

According to the national rules on the revaluation of tangible fixed assets, the revaluation reserve related to the depreciable tangible fixed asset is transferred onto the retained earnings when they are fully depreciated, decommissioned, sold, or transferred free of charge. The IPSAS 17 'Property, Plant and Equipment' adds to the national rules regarding the surplus achieved from the revaluation of tangible fixed assets. It specifies that a portion of the surplus made while the fixed assets are being used can be transferred to the retained earnings and is calculated as the difference between the value of the depreciation, based on the revaluated accounting value of the assets and the cost-based depreciation.

As previously mentioned, the tangible fixed assets that are subject to revaluation are presented in the balance sheet as their revaluated value. The value of these assets as at the balance sheet date influences the value of the total assets as an increasing or decreasing trend, depending on the results of the reassessment. The financial position of the public institution is given by the value of its assets, liabilities, and capital. As the total asset value is influenced by the value of the tangible fixed assets resulting from the revaluation, conceivably the financial position equally depends on the results of the revaluation.

The value resulting from the revaluation will replace the initial value of the tangible fixed assets, and in the case of depreciable assets, the depreciation is calculated by taking the reassessed value into account. Therefore, the expenses incurred from the depreciation of the tangible fixed assets will be lower or higher depending on the depreciable value. The patrimony of public institutions is determined as the difference between the recorded revenue and the expenditure, including the depreciation expenses. Thus, the depreciation expenditure will influence the patrimonial result for the public institution.

In conclusion, the revaluation of the depreciable and non-depreciable tangible fixed assets affects the financial position, while the revaluation of depreciable tangible fixed assets influences the patrimonial outcome.

\section{Conclusion}

The Romanian accounting system has undergone a comprehensive reform. Consequently, the accounting system of the public institutions in Romania follows the accrual accounting principle and has largely implemented the provisions of the international reporting standards for the public sector. The adoption of rules on the revaluation of tangible fixed assets was part of the reform. The revaluation installs the present value of the tangible fixed assets owned by public institutions, providing an accurate and fair presentation of assets. Both, the national accounting regulations and the international standard on the tangible assets of public entities provide accounting treatments for determining the value of the assets as at the balance sheet date. The basic treatment by which the tangible fixed assets appear on the balance sheet as a cost below the depreciation value and the alternative treatment that allows the presentation of tangible fixed assets at their fair value on the balance sheet, both, provide a value resulting from the revaluation process. Public institutions can apply a single treatment to establish the balance sheet value of the tangible fixed assets. Unlike the international accounting standards for the public sector, the national rules on the revaluation of the tangible fixed assets, owned by public institutions, provide for the compulsory revaluation of land and buildings at least once every three years. There are divergences between the national rules on the revaluation of the tangible fixed assets owned by public institutions and that of the international accounting standards for the public sector. These concern who is responsible for determining the fair value resulting from revaluation; setting up the fair value; the accounting treatment of the revaluation results; and the revaluation surplus achievement. The revaluation of the tangible fixed assets plays a major role in determining the current value of assets, thereby presenting a true and fair image of the financial and patrimonial position of a public institution. 


\section{References}

Government Ordinance on the reassessment and amortization of tangible fixed-assets owned by the public institutions, no. 81 , art. 9, 2003

Handbook of International Public Sector Accounting Pronouncements, Vol. I, International Federation of Accountants, 587, 2016

Order of the Minister of Economy and Finances approving the methodological norms on the reassessment and amortization of tangible fixed-assets owned by the public institutions, no. 3471, art. 3- 6, 2008

Order of the Minister of Public Financesfor the approval of the methodological norms regarding the organization and management of the bookkeeping department of public institutions, the plan of accounts for public institutions and its enforcement instructions, no. 1917, 2005

M Ristea, I Jianu I, I Jianu, The Romanian Experience in Applying the International Standards for Financial Reporting as well as the International Public Sector Accounting Standard, The Transylvanian Magazine for Administrative Sciences, 1, 169-192, 2010, from http://rtsa.ro/rtsa/index.php/rtsa/article/view/102/98

C Luca, Revaluation and Amortization of Fixed-assets, a Novelty in the Accounting Policies of the Ministry of National Defense Military Units, The Bulletin of the Carol I National Defense University, 4, 156-165, 2010, from https://www.ceeol.com/search/article-detail?id=126217 